\title{
Parental Participation in Provision of Infrastructural Facilities and Their Influence on Students' Performance in Public Day Secondary Schools in Gem Sub County, Kenya
}

\author{
James Ochieng Sika \\ Department of Education Management and Foundation, Maseno University, Maseno, Kenya \\ E-mail: drjamessika@yahoo.com
}

Received: March 8, 2019 Accepted: July 20, 2019 Published: July 24, 2019

doi: 10.5296/ire.v7i2.14477 URL: https://doi.org/10.5296/ire.v7i2.14477

\begin{abstract}
The role of parents was seen as the missing link in provision of infrastructural facilities leading to achievement of desirable performance as the government fulfilled her mandate of providing free education through the Free Day Secondary Education funds. Descriptive survey design was used. The study population included 20 principals, 184 teachers, 776 parents and 776 students. The respondents who were sampled through purposive, incidental and random sampling method included principals, parents, teachers' and form four students. The study shows there was a significant relationship between Provision of Infrastructural Facilities and students' performance $(\mathrm{R}=.594 ; \mathrm{p}<.001)$. The results of the regression indicated that parents' participation in provision of Infrastructural Facilities explained 35.2\% of the variance in students' performance $\left(\mathrm{R}^{2}=.352, \mathrm{~F}(1,239)=130.105, \mathrm{p}<.001\right)$. It was found that parents' participation in provision of Infrastructural Facilities significantly predicted performance of MFIs $(\mathrm{B}=.376 ; \mathrm{p}<.001)$. By replacing the significant coefficients into the equation connecting parents' participation in provision of Infrastructural Facilities with students' performance, the equation becomes $\mathrm{Y}=24,768+0.376 \mathrm{X}_{2}+: \varepsilon$. Library, toilets and laboratory in day secondary schools were found to be inadequate hence affecting their performance. The study recommends that parents should be involved in infrastructure development secondary schools as this could influence academic achievement.
\end{abstract}

Keywords: Academic, Parents, Performance, Physical facilities, Secondary schools 


\section{Introduction and Background}

Governments all over the world are spending large amounts of money in improving the infrastructure in schools. Education plays a crucial role in preparing the young for their roles in society. Musyoka, (2013). In the World Conference on Education for all (EFA) held in Jomtien in Thailand in 1990, it was agreed that education is a basic need for all people. In Africa, this declaration was domesticated by Dakar framework of Action (2000).In this conference several elements necessary for quality education were identified as follow; motivated students, well trained teachers using actual learning techniques, adequate facilities and materials, local language curriculum that builds the teachers and learning knowledge and experience, welcoming gender sensitive, health, safe environment that encourage learning and accurate assessments of learning outcomes (UNESCO, 2000).

Though facilities are taken for granted in developed nations of the world, the problems related to facilities are endemic in many developing countries. The availability of classrooms with reasonable sizes, libraries and other infrastructure are closely linked to performance (Haneveld \& Craig, 1996). The World Bank contributes many capital intensive investments in school facilities in Africa (The World Bank, 1995). The Bank's funds are mostly used on other educational inputs apart from buildings. School facilities have been underscored as one of the factors that enhance students' persistence with school (Wachiye, 1996). Differences in availability of schools laboratories, visual aids, electricity and play fields seem to account for the differences in schools performance.

The presence or absence of facilities distinguishes high or low efficient schools. In tackling the issue of facilities it was necessary to investigate the presence and conditions of such school facilities like toilets. The absence and poor conditions of such school facilities have potentially negative effects on students' persistence with school. Stakeholders are expected to focus on providing and improving these critical facilities. This study intended to bring out the contributions that parents have brought in the provision of infrastructural facilities in day schools in face of the introduction of Free Day Secondary Education (FDSE) and the government policy of no extra levy paid by the parents except the parental obligations which include school uniform, lunch for day scholars and other projects of infrastructure approved by the County Education Board (CEB) in consultation with the Board of Management (BOMs) and Parents Association (PAs)

In Gem Sub County, most parents of day schools do not contribute adequately to physical development. Standard and Quality Assessment Report Gem Sub County (2015). This role has been left to National Government Constituency Development Fund (N.G.C.D.F.). The parents are so dependent on external sources of funds that make it difficult to develop the necessary infrastructure in day schools that can spur any meaningful academic performance. In boarding schools in the Sub County, parents seem to have a different attitude towards provision of physical facilities. Backed by development funds, the infrastructural facilities are more improved compared to those of day schools.

\subsection{Statement of the Problem}

The performance of day secondary schools in Gem Sub County between the year 2013 and 2015 has consistently been low and fluctuating. In 2015 for instance Day schools recorded an 
average performance of $39.15 \%$ pass, $37.44 \%$ in 2014 and $42 \%$ pass in 2013 . The development of infrastructure is largely done by the government through the National Government Constituency Development Fund yet this is also a shared responsibility with parents. Most day schools in Gem Sub County lack the basic infrastructure like classrooms, playfield and or administration block and only 7 out of the 32 schools, a paltry $21.8 \%$ of all public secondary schools have functional laboratories yet this is a requirement for achieving desirable academic success. If this trend is allowed to persist, probably Gem as a Sub County may continue to register few students in tertiary institutions something that will have significant effect on Gem Sub - County in the long run. The study intended to examine the roles of parents in provision physical facilities and their influence on students' performance in public day schools with a view to establishing the performance of parents in these institutions.

\section{Literature Review}

Provision of quality education is enhanced by providing adequate physical infrastructure which includes laboratory, library, dormitory and classroom. These play an important role in enhancing safe and clean environment which is conducive for high achievement and physical comfort. Heyman (1980) supports the idea (as cited in Beynon, 1997) that developing countries low levels of learning among children can be partly attributed to poor and inadequate physical infrastructure in schools. The differential academic achievement of students in examinations has been of concern to researchers and parents, world over. There has been a long assumption that curriculum and teaching have an impact on learning. However, it is becoming more apparent that physical infrastructure of school can influence student achievement (O’Lagbemiro, 2010).

Similar sentiments were given by Lyons (2002) who said that learning is a complex activity that puts students' motivation and physical conditions to test. Several studies have been carried to establish the influence of physical facilities on student $\mathrm{s}$ performance in examinations. Studies have shown that in most schools laboratory activities, student guides, handbook or worksheet continue to play a central role in shaping the students behavior and learning. In study done by Cash (1993) it was found that air condition, absence of graffiti, condition of science laboratory, and condition of library facilities correlated with student academic achievement at a significant level when controlling the socio economic status of the student. Chan (1996) conducted a similar study of the impact of physical infrastructure on student performance. Chan (1996) concluded that technology and adaptability of physical infrastructure better equipped student for success and that to ignore the fact was to disregard the physical difficulties of learning. On classroom size studies have shown that students in larger classes may perform more poorly if the resulting reduced motivation leads to increased absenteeism.

In Nigeria, a lot of studies have been conducted by various researchers on the relationship between educational resources and students' academic performance. Idiagbe (2004) concluded that teachers qualification and adequate facilities were determinants of academic performance of students in secondary schools. Hence the availability or non-availability of facilities in schools affects academic performance of students in Delta state. This is in agreement with Nwangwu, (1997) who believed that teaching and learning activities help the 
school to determine the number of pupils to be accommodated, the number of teachers and non-teaching staff.

In Kenya a number of studies have been conducted to assess the level of availability and adequacy of teaching and learning facilities in the schools. According to Musyoka (2013) it was concluded that Science laboratory is central to scientific instructions and it forms essential component of science education without proper and well equipped science laboratory, it is not possible to carry out the science teaching process effectively in any other school or educational institution. Library is a section of the school organization where there is a collection of books, magazines, articles and newspapers. Some schools have audio - visual section in their library. The need for a good library service is no longer an issue of debate. A library is therefore indispensable because it is the hub of intellectual activities in the school just like as laboratory. Musyoka, (2013) also contends that teaching learning process take place and that the spacious classrooms give the teachers and students good room for interaction.

Most of the studies conducted in developing countries on the role of physical facilities on academic performance mainly concentrated on role of government in provision of the same facilities in order to attain the Education for All (EFA) goal. This study mainly concentrated on the role of parents on provision of physical facilities in day schools and how their level of participation affected performance

\section{Research Design and Methodology}

\subsection{Research Design}

In order to achieve the objectives of the study a descriptive survey design based on questionnaire was used because the study objectives were descriptive in nature and may also require taking care of multiple reality likely to be found in the field (Amin, 2005). According to Mugenda and Mugenda (2003), the method is easy to manage and administer. Quantitative method was used in order to establish the extent and rate of the problem. Emphasis was put on collecting data from stakeholders in school administration. Hence questionnaire was used to collect information from principals, teachers, parents and students. The data was described and summarized graphically.

\subsection{Sample Size and Sampling Technique}

The list of schools was obtained from the Gem Sub County director of education's office. Of the 20 public day schools, $10 \%$ of the total number of schools i.e. two schools precisely was used for pilot study. The remaining 18 day schools and their principals were purposively selected to participate in the study. A simple random sampling method was used to select 6 teachers and 10 students in form four in each school. The rationale for choosing form four students in the school is that they have been in school longer to articulate the issues at hand; they are also old enough to give credible information compared to their counterparts in junior classes. 
Table 1. Summary of sample size

\begin{tabular}{llll}
\hline \multicolumn{1}{c}{ Category of respondent } & Total population & No. selected & Sampling Technique \\
\hline Principals & 20 & 18 & Purposive \\
Teachers & 184 & 108 & purposive \\
Parents & 776 & 72 & Incidental or volunteer \\
Students & 776 & 180 & Simple random \\
\hline
\end{tabular}

\subsection{Data Analysis Procedure}

The responses to the closed - ended items in the data collection instrument were assigned codes and labels. Data was analyzed using both descriptive and inferential statistics. Frequencies, percentages, and mean score were used. Frequency counts of responses were obtained to generate descriptive information about the respondents and to illustrate the general trend of the findings on various variables that were under investigation. This was done with help of Statistical Package for Social Science (SPSS). According to Mugenda and Mugenda (2003); the use of these methods helped to summarize large quantities of data whilst making the report reader friendly. The data was presented using statistical technique mainly tables.

\section{Results and Discussion}

\subsection{Parents' Participation in Provision of Infrastructural Facilities in School}

The respondents were asked to indicate whether parents participate in the provision of infrastructural facilities in their respective schools. The findings are presented in the Table.

Table 2. Parents' participation in provision of infrastructural facilities in school

\begin{tabular}{lllllllllll}
\hline & \multicolumn{2}{c}{ Principal } & \multicolumn{2}{c}{ Teachers } & \multicolumn{2}{c}{ Parents } & \multicolumn{2}{c}{ Students } & \multicolumn{2}{c}{ Overall } \\
& F & $\mathbf{\%}$ & F & $\mathbf{\%}$ & F & \% & F & \% & F & \% \\
\hline Strongly Disagree & 1 & $5.6 \%$ & 12 & $12.1 \%$ & 6 & $9.1 \%$ & 21 & $12.1 \%$ & 40 & $11.2 \%$ \\
Disagree & 5 & $27.8 \%$ & 17 & $17.2 \%$ & 15 & $22.7 \%$ & 40 & $23.1 \%$ & 77 & $21.6 \%$ \\
Undecided & 2 & $11.1 \%$ & 20 & $20.2 \%$ & 11 & $16.7 \%$ & 32 & $18.5 \%$ & 65 & $18.3 \%$ \\
Agree & 7 & $38.9 \%$ & 29 & $29.3 \%$ & 25 & $37.9 \%$ & 45 & $26.0 \%$ & 106 & $29.8 \%$ \\
Strongly Agree & 3 & $16.7 \%$ & 21 & $21.2 \%$ & 9 & $13.6 \%$ & 35 & $20.2 \%$ & 68 & $19.1 \%$ \\
Total & $\mathbf{1 8}$ & $\mathbf{1 0 0} \%$ & $\mathbf{9 9}$ & $\mathbf{1 0 0 \%}$ & $\mathbf{6 6}$ & $\mathbf{1 0 0} \%$ & $\mathbf{1 7 3}$ & $\mathbf{1 0 0 \%}$ & $\mathbf{3 5 6}$ & $\mathbf{1 0 0 \%}$ \\
\hline
\end{tabular}

From the findings in Table 2, majority of the principals $(38.9 \%)$ agreed that parents participate in provision of infrastructural facilities in the school while $16.7 \%$ strongly agree. This shows that $55.6 \%$ of the principals cumulatively agreed that parents participate in provision of infrastructural facilities in the school. However, $33.4 \%$ of the principals cumulatively disagreed (5.6\% strongly disagree; $27.8 \%$ disagree) that parents participate in provision of infrastructural facilities in the school. This shows that, according to principals, a significant $33.4 \%$ of the parents do not participate in provision of infrastructural facilities in the school. Similarly, $50.5 \%$ of the teachers cumulatively agreed $(21.2 \%$ strongly agree; $29.3 \%$ agree) that parents participate in provision of infrastructural facilities in the school with only $29.3 \%$ of the teachers cumulatively disagreeing that parents participate in provision 
of infrastructural facilities in the school. This shows that in as much as teachers consider parents to actively participate in the provision of infrastructural facilities, there are some schools or among some parents where this is not happening.

Further, the finding shows that parents generally believe that they participate in provision of infrastructural facilities in the school with $51.5 \%$ cumulatively agreeing with the statement. Specifically, $37.9 \%$ of the parents agree that parents participate in provision of infrastructural facilities in the school while $13.6 \%$ strongly agree. However, $31.8 \%$ of parents cumulatively disagree that parents participate in provision of infrastructural facilities in the school $(22.7 \%$ disagree; $9.1 \%$ strongly disagree.

As for the students, $46.2 \%$ cumulatively agreed that parents participate in provision of infrastructural facilities in the school with $35.2 \%$ cumulatively disagreeing. This shows that some of the parents in some of the public secondary schools do not participate, as expected, on infrastructural facilities. Overall, $29.8 \%$ of the respondents agree that parents participate in provision of infrastructural facilities in the school with $19.1 \%$ strongly agreeing. However, $32.8 \%$ of the respondents cumulatively disagreed that parents participate in provision of infrastructural facilities in the school. This finding shows that parents in Gem Sub-County averagely participate in provision of infrastructural facilities. Thus, the remaining $50 \%$ or more of the parents who do not participate in provision of infrastructural facilities ultimately affects students' performance.

\subsection{Availability and Adequacy of Facilities}

Having established parents participation in the provision of infrastructural facilities, the research sought to establish the adequacy of such facilities. The finding for 356 respondents was summarized into frequency and percentages as shown in Table 3.

Table 3. Availability and adequacy of facilities

\begin{tabular}{|c|c|c|c|c|c|c|c|c|c|c|}
\hline \multirow[t]{2}{*}{ Facilities } & \multicolumn{2}{|c|}{$\begin{array}{l}\text { Very } \\
\text { inadequate }\end{array}$} & \multicolumn{2}{|c|}{ Inadequate } & \multicolumn{2}{|c|}{ Not sure } & \multicolumn{2}{|c|}{ Adequate } & \multicolumn{2}{|c|}{$\begin{array}{l}\text { Very } \\
\text { adequate }\end{array}$} \\
\hline & $\mathbf{F}$ & $\%$ & $\mathbf{F}$ & $\%$ & $\mathbf{F}$ & $\%$ & $\mathbf{F}$ & $\%$ & $\mathbf{F}$ & $\%$ \\
\hline $\begin{array}{l}\text { Teacher's } \\
\text { furniture }\end{array}$ & 19 & $5.3 \%$ & 31 & $8.7 \%$ & 51 & $14.3 \%$ & 159 & $44.7 \%$ & 96 & $27.0 \%$ \\
\hline Classrooms & 23 & $6.5 \%$ & 29 & $8.1 \%$ & 54 & $15.2 \%$ & 133 & $37.4 \%$ & 117 & $32.9 \%$ \\
\hline Laboratory & 76 & $21.3 \%$ & 105 & $29.5 \%$ & 65 & $18.3 \%$ & 73 & $20.5 \%$ & 37 & $10.4 \%$ \\
\hline Library & 87 & $24.4 \%$ & 133 & $37.4 \%$ & 77 & $21.6 \%$ & 33 & $9.3 \%$ & 26 & $7.3 \%$ \\
\hline Toilets & 63 & $17.7 \%$ & 97 & $27.2 \%$ & 113 & $31.7 \%$ & 52 & $14.6 \%$ & 31 & $8.7 \%$ \\
\hline $\begin{array}{l}\text { Students desks } \\
\text { and chairs }\end{array}$ & 15 & $4.2 \%$ & 37 & $10.4 \%$ & 112 & $31.5 \%$ & 151 & $42.4 \%$ & 41 & $11.5 \%$ \\
\hline I.C.T. facilities & 98 & $27.5 \%$ & 125 & $35.1 \%$ & 69 & $19.4 \%$ & 37 & $10.4 \%$ & 27 & $7.6 \%$ \\
\hline
\end{tabular}

The findings show that teachers' furniture was adequate in most schools as rated by $44.7 \%$ of the respondents. Further, $27 \%$ of the respondents rated teachers' furniture as very adequate. This shows that $71.7 \%$ of the respondents cumulatively agree that teachers' furniture in their respective schools is adequate. Similarly, the classrooms were also found to be generally 
adequate among public secondary schools in Gem Sub-County. This emerged as $37.4 \%$ of the respondents indicated that classrooms were adequate while $32.9 \%$ indicated that they were very adequate.

Further, student desks and chairs were found to be adequate across the schools with majority of the respondents (42.4\%) rating it as adequate while $11.5 \%$ rated it as very adequate. This gives a cumulative $53.9 \%$ of the respondents who generally consider students' desks and chairs to be adequate. This almost average finding gives an indication that there are a considerable proportion of the respondents (46.1\%) who see the desks and chairs in the schools as inadequate.

However, laboratories were found to be inadequate with $29.5 \%$ of the respondents indicating that it was inadequate while another $21.3 \%$ rated it as very inadequate. Thus cumulatively, $50.5 \%$ of the respondents rated laboratory as inadequate. This finding shows that laboratories as inadequate in majority of the schools. Similarly, the libraries were found to be inadequate as rated by majority of the respondents (37.4\%) with another $24.4 \%$ rating libraries as being very inadequate. The overall inadequate in both libraries and laboratories affect the performance of students as they lack the very important facilities to help them acquire knowledge in sciences and for regular studies.

Further, ICT facilities in the public secondary schools in Gem Sub-County were also found to be inadequate. This emerged as $35.1 \%$ of the respondents indicated that ICT facilities in their schools were inadequate as additional $27.5 \%$ rated it as very inadequate. Overall, $62.6 \%$ of the respondents cumulatively rated the ICT facilities as inadequate. The inadequate ICT facilities pose various challenges to learning such as evaluation, progress record monitoring and modern technological learning methods thus ultimately affecting performance.

\section{Teaching Resource Adequacy}

The researcher also sought opinion on adequacy of teaching/learning materials. The teachers were asked to rate various teaching/learning resources in the school as $1=$ Very inadequate, 2 = Inadequate, $3=$ Not sure, $4=$ Adequate, $5=$ Very Adequate. The finding for 99 teachers who participated in the study was summarized into frequency and percentages as shown in Table 4.

Table 4. Teaching resource adequacy

\begin{tabular}{|c|c|c|c|c|c|c|c|c|c|c|}
\hline \multirow[t]{2}{*}{ Resource Adequacy } & \multicolumn{2}{|c|}{$\begin{array}{l}\text { Very } \\
\text { inadequate }\end{array}$} & \multicolumn{2}{|c|}{ Inadequate } & \multicolumn{2}{|c|}{ Not sure } & \multicolumn{2}{|c|}{ Adequate } & \multicolumn{2}{|c|}{$\begin{array}{l}\text { Very } \\
\text { adequate }\end{array}$} \\
\hline & $\mathbf{F}$ & $\%$ & $\mathbf{F}$ & $\%$ & $\mathbf{F}$ & $\%$ & $\mathbf{F}$ & $\%$ & $\mathbf{F}$ & $\%$ \\
\hline Improved teaching & 16 & $(16.2)$ & 29 & $(29.3)$ & 36 & $(36.4)$ & 11 & $(11.1)$ & 7 & (7.1) \\
\hline $\begin{array}{l}\text { Teacher prepared } \\
\text { teaching aids }\end{array}$ & 10 & $(10.1)$ & 33 & $(33.3)$ & 29 & $(29.3)$ & 15 & $(15.2)$ & 12 & $(12.1)$ \\
\hline Textbooks & 13 & $(13.1)$ & 17 & & 18 & $(18.2)$ & 29 & (29.3) & 22 & $(22.2)$ \\
\hline Exercise books & 5 & $(5.1)$ & 16 & $(16.2)$ & 17 & $(17.2)$ & 35 & $(35.4)$ & 26 & $(26.3)$ \\
\hline
\end{tabular}

From the findings, a cumulative majority of teacher-respondents $(45.5 \%)$ rated improved teaching aids as inadequate while $36.4 \%$ were not sure. Specifically, $29.3 \%$ of the 


\section{Macrothink

teacher-respondents considered teaching aids to be inadequate while $16.2 \%$ considered it to be very inadequate. Only $18.2 \%$ rated the improved teaching aids as inadequate cumulatively. This shows that improved teaching aids are generally inadequate among the schools which affects content delivery to the learners thus their performance. Similarly, teacher prepared teaching aids were also found to be inadequate with majority of the respondents $(33.3 \%)$ rating the teacher prepared teaching aids as inadequate. Further, $10.1 \%$ of the respondents rated teacher prepared teaching aids as very inadequate giving a cumulative $43.4 \%$ of the teacher respondents who consider teacher prepared teaching aids to be inadequate. However, $29.3 \%$ of the teacher respondents were not sure whether teacher prepared teaching aids were adequate or not.

Textbooks and exercise books were found to be generally adequate according to the teachers rating. Specifically, majority of the teachers cumulatively rated textbook availability as adequate $(51.5 \%)$ as was the case with exercise books where majority $(61.7 \%)$ rated it as adequate. Thus although textbooks and exercise books were found to be adequate among the schools in Gem Sub-County; the inadequacy in teaching aids affects the overall performance of the learners.

\section{Influence of Parents Participation in Provision of Infrastructural Facilities on Students Performance}

In order to establish the influence of parental participation in provision of infrastructural facilities on students' performance, a regression analysis was conducted between scores of students rating of parental participation in provision of facilities and the students latest mean scores in the end of term exams. The regression equation was of the form:

$$
Y=B_{0}+B_{2} X_{2}+\varepsilon_{1}
$$

Where $\mathrm{Y}$ is students' performance, $\mathrm{B}_{0}$ is the coefficient of the constant term relating performance and provision of infrastructure, $\mathrm{B}_{1}$ is coefficient of provision of infrastructure, $\mathrm{X}_{1}$ is provision of infrastructure and $\varepsilon_{1}$ is error term for the equation. Consequently, the regression output is presented in Table 5 
Table 5. Regression Output for Parents Participation in Provision of Infrastructural Facilities and Students Performance

Model Summary ${ }^{b}$

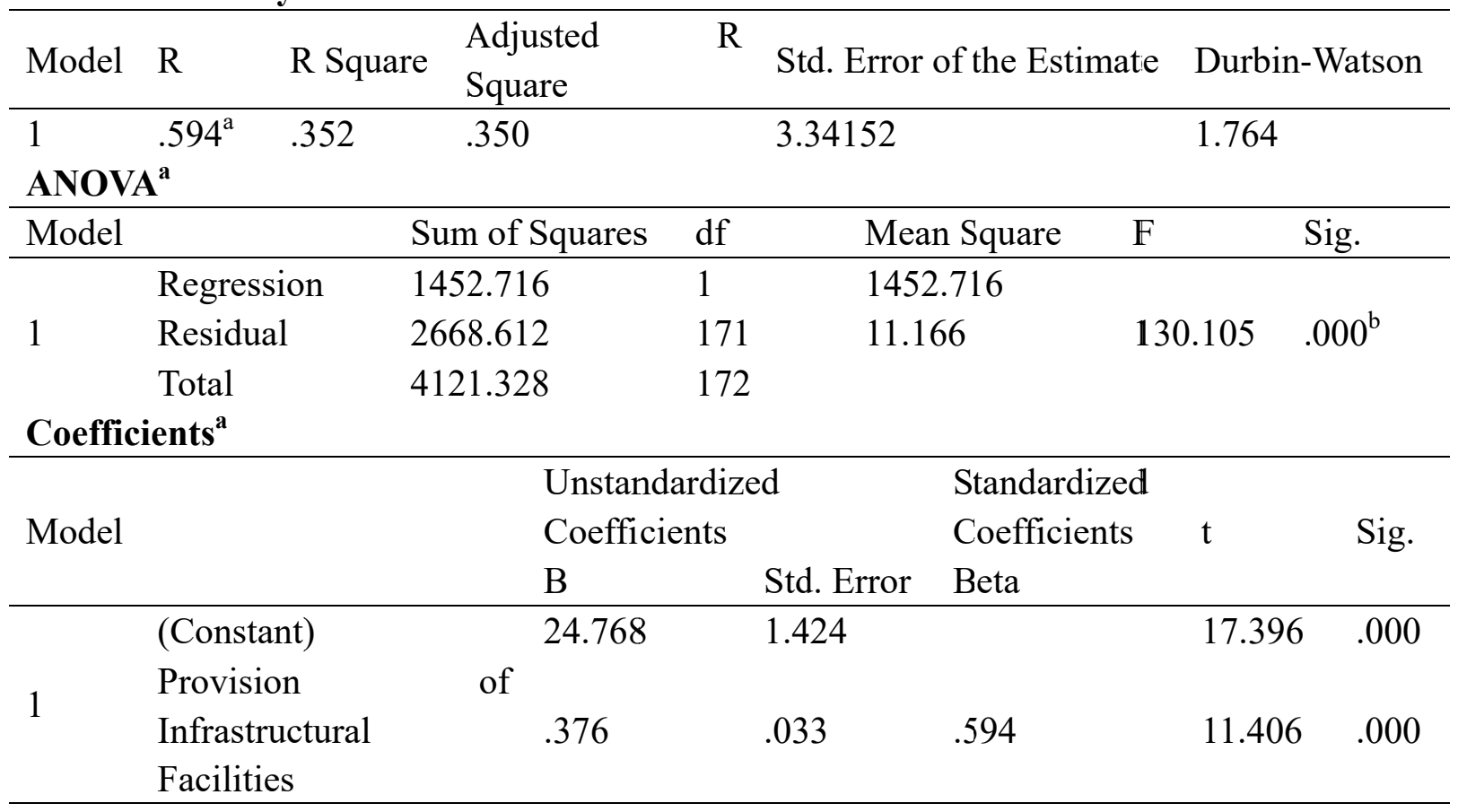

From the findings in Table 5, there was a significant relationship between Provision of Infrastructural Facilities and students' performance $(\mathrm{R}=.594 ; \mathrm{p}<.001)$. Regression analysis was used to test if parents' participation in provision of Infrastructural Facilities significantly predicted students' performance. The results of the regression indicated that parents' participation in provision of Infrastructural Facilities explained $35.2 \%$ of the variance in students' performance $\left(\mathrm{R}^{2}=.352, \mathrm{~F}(1,239)=130.105, \mathrm{p}<.001\right)$. It was found that parents' participation in provision of Infrastructural Facilities significantly predicted performance of MFIs $(\mathrm{B}=.376 ; \mathrm{p}<.001)$. By replacing the significant coefficients into the equation connecting parents' participation in provision of Infrastructural Facilities with students' performance, the equation becomes:

$$
\mathrm{Y}=24.768+0.376 \mathrm{X}_{2}+\varepsilon_{2}
$$

This shows that enhanced parents' participation in provision of Infrastructural Facilities in schools leads to improved students' performance.

\section{Conclusion}

The study concluded that most parents participated in provision of infrastructural facilities in the school. As much as teachers consider parents to actively participate in the provision of infrastructural facilities, there are some schools where this is not happening as expected. The overall inadequate in both libraries and laboratories affect the performance of students as they lack the very important facilities to help them acquire knowledge in sciences and for regular studies. This shows that enhanced parents' participation in provision of Infrastructural Facilities in schools leads to improved students' performance. 


\section{Recommendations}

The government should have a systematic method of identifying and funding infrastructure in day secondary schools in order to improve their status because they are the schools with majority of the learners. Due to poverty and related economic hardships, parents are doing little in financing physical facilities. However, at their level, they should be encouraged to contribute in building physical facilities through fundraising, donations and active engagement in mobilizing resources for day secondary schools.

\section{References}

Amin, M. E. (2005). Social Science Research: Conception, methodology and analysis. Kampala: Makerere University.

Babirye, A. (2006). The Role of Parents in the Management of School Activities in Government Aided primary schools in Nakifuma county Mukono District ${ }_{2}$ MA Dissertation Makerere University Kampala.

Beynum, J. (1997). Physical Facilities for Educational: What Planners needs to know. Fundamental of Educational Planning

Bryan J. B. (2005). Fostering educational resilience and achievement in urban schools through School - family community partnerships. Professional school of counseling.chool Building

Cash, C. (1993). Building Conditions and Students Achievement and Behaviour. Blacksburg, V.A: Virginia polytechnique Institute and State University

Chan, T. C. (1979). The Impact of School Building Age on Pupils Achievement.

Desforges, A., \& Abouchaar, A. (2003). Impact of parental Involvement, Parental Support and family Education on Pupil Achievement and Adjustment: A literature Review, Research Report No.433, Queens Printer.

Feyfant, A., \& Olivier (2006). The Role played Parents in achieving Success at School.

Georgiou, S. N. (2007). Parental Involvement: Beyond Demographics. International Journal about Parents in Education, 1, 59-62.

Heneveld, W., \& Craig, H. (1996). School Count: World Bank Project Designs and Quality of Africa Primary Education. World Bank, Washington, D.C. https://doi.org/10.1596/0-82133460-3

Idiagbe, J. E. (2004). Relationship between Education Facilities, Teacher Qualifications, School Location and Academic Performance of Students in Secondary Schools in Delta State. (Unpublished Ph.D Thesis. Delta state University, Abraka).

Lyons, J. B. (2002). The Learning Environment: Do Facilities really affect a child's education? Learning By Design, 11, 10-13. https://doi.org/10.1177/104515950201300203

Mbita, E. M. I. S. (2015). Annual Educational Assessment and Evaluation Reports. Unpublished Mbita Sub County Education Office: Education Day Report.

Moest. (2015). Homabay County Education Report, KCSE Analysis.

Mugenda, O. M., \& Mugenda, A. G. (2003). Research Methods; Quantitative and Qualitative Approaches. Nairobi: Acts Press.

Musyoka, L. (2013). Influence of Provision of School Physical Infrastructure on Student 
performance in Kenya Certificate of Secondary Education in Mwingi Central District, Kenya. Nwangu, N. A. (1997). The Environment of crisis in Nigeria Educational System. Co-operative Education, 33(1), 87-95. https://doi.org/10.1080/03050069728659

Republic of Kenya. (2013). The Basic education Act, 2013, Nairobi, Kenya: Government Printers.

Wachiye, H. R. (1996). An Investigation in the Probable Causes of Poor Performance, Disparity in Butunge Zone of Sirisia Divion, Bungoma District. Nairobi, Kenya. Unpublished Thesis, Kenyatta Univrsity.

UNESCO. (2000). World Education Report. Paris France.

\section{Copyright Disclaimer}

Copyright reserved by the authors.

This article is an open-access article distributed under the terms and conditions of the Creative Commons Attribution license (http://creativecommons.org/licenses/by/3.0/). 